\title{
Species Composition, Diversity and Length Frequency of By- Catch Sharks from the Syrian Coast
}

\author{
Hasan ALKUSAIRY ${ }^{\mathrm{a} *}$, Adib SAAD ${ }^{\mathrm{a}}$ \\ ${ }^{a}$ Marine Sciences Laboratory, Faculty of Agriculture, Tishreen University, Lattakia, Syria.
}

*Corresponding Author: Hasan ALKUSAIRY, Marine Sciences Laboratory, Faculty of Agriculture, Tishreen University, Lattakia, Syria.

\begin{abstract}
This study examines the species diversity, abundance, length structure, sex ratio and possible nursery of caught sharks and from Syrian marine waters during the period from November 2014 to October 2016. A total of 17 species were recorded belonging to 11 families. The most abundant family was the Squalidae, contributing $28.33 \%$ to the total number of recorded shark species. The species Galeus melastomus was the most abundant 26.85\%. The two families Hexanchidae and Carcharhinidae contributed $88.59 \%$ of the total weight of species, the most weight species was Hexanchus griseus 47.02\%. The diversity index $H$, qualitative richness factor $D$ and evenness factor J means \pm S.D. were $1.70 \pm 0.22,1.88 \pm 0.35$ and $0.67 \pm 0.08$ respectively. The seasonally variation of the $H$ and $D$ means showed a high values in spring, while J mean showed a high value in winter. There were three abundant species and five common species off the Syrian coast. Many species comprised a high proportion of juveniles. Length structure analysis showed that sustainable populations for many species, which probably established in the Syrian marine waters, this region could be considered as a possible nursery area for many species.
\end{abstract}

Keywords: elasmobranches, biodiversity, length structure, nursery areas, Syrian coast.

Abbreviations: H: diversity index, D: qualitative richness factor, J: evenness factor:, TL: total length

\section{INTRODUCTION}

Cartilaginous fishes off the Syrian coast have not been studied systematically as yet. To date, fortyfour chondrichthyans species $[1,2,3,4,5,6]$ were recorded in Syrian coast. In the Syrian marine waters, information related with the biology, fishery, landings, distribution and abundance of shark populations is scarce or non-existent. There were few studies interested in species survey and taxonomy $[1,2]$, species biology $[7,8,9]$. Whereas there were no studies on landings, distribution, abundance and structure of shark populations in this area.

Chondrichthyans are vulnerable to overexploitation. Globally, lack of accurate catch data (due to under reporting, lack of by catch recording, poor species identification and species wise catch data, illegal fishing etc.) makes assessment and management of chondrichthyans exploiting difficult, which is a major concern. This issue was addressed by Convention on international Trade in Endangered Species (CTES) in 1994, which requested contracting parties to collect biological and trade information on sharks taken in their fisheries. This was reiterated by FAO in 1999 by its adoption of International Plan of Action (IPOA) for Conservation and management of sharks. At present, only a few countries have management and monitoring programs for chondrichthyans.

Sharks have experienced increased demand in recent years due to rise of bony fish price and the request increasing on fish; despite Syria has no targeted sharks fishery. Although the diversity of cartilaginous fish, there are no studies have been undertaken to determine the biological characteristics of the shark catches or its ability to withstand this increased exploitation, The present study was undertaken as a first step to remedying this situation, which aimed to provide the first detailed assessment of the compositions and abundances of shark in Syrian marine waters. The length structure, sex compositions and possible nursery places of abundant and common species were determined. 


\section{MATERIALS AND MethodS}

During November 2014 to October 2016, daily surveys were made on species and its size structure which caught by all fishing gears (mainly: bottom trawl, bottom longlines, nets) in the main landing of chondrichthyans in Lattakia city. Species identification was made following [10], [11] and [12]. Total length (TL) and weight measurements taken to the nearest $\mathrm{cm}$ and $\mathrm{kg}$, respectively. The ecological indices; diversity index $\mathrm{H}$, qualitative richness factor $\mathrm{D}$ and Evenness factor $\mathrm{J}$ were used to evaluate the levels of shark diversity within the study region by all gear types, diversity index $\mathrm{H}$ was calculated following [13]:

$$
\mathrm{H}=-\sum_{\mathrm{i}=1}^{\mathrm{s}} \mathrm{Pi} \times \ln (\mathrm{Pi})
$$

where $\mathrm{S}$ is the number of species in the sample, $\mathrm{Pi}$ is the proportion that the $\mathrm{i}^{\text {th }}$ species contributes to the total abundance of the sample $(\mathrm{Pi}=\mathrm{Ni} / \mathrm{N})$, Ni the number of individuals of the $\mathrm{i}^{\text {th }}$ species, and $N$ the number of individuals in the sample.

.Qualitative richness factor D by equation: following [14]

$$
\mathrm{D}=\frac{(\mathrm{S}-1)}{\ln (\mathrm{N})}
$$

Evenness factor J by equation: according [15]

$$
\mathrm{J}=\frac{\mathrm{H}}{\ln (\mathrm{S})}
$$

SPSS 20 were used to analyze data, all information on total length at first maturity of the Syrian marine fishes or the nearest region to Syrian coast were extracted from peer-reviewed published sources, including 'grey' literature covering the period up to April 2017. Possible nursery places were defined depending on individuals size of species, density of individuals and repeat individuals appearance in the fishing area.

\section{RESULTS AND DISCUSSION}

A total of 4158 and 3877 individuals of sharks species were recorded in first and second year respectively of study period, there were no significant differences between first and second year ( $\mathrm{t}-$ test, $t=0.638, \mathrm{P}>0.05$ ), consequently, samples through two years were studied as a one year totally.

A total of 8035 elasmobranches individuals, comprising 17 species belonging to 11 families, were recorded at main landing site in the Syrian coast between November 2014 to October 2015 (Table 1). Whereas 21 shark species were recorded off Syria marine water throughout the period 2003-2012 [1, 2 , 4]. The species that did not record in this study, but it was recorded in prior studies were, Somniosus rostratus, Squatina squatina, Cetorhinus maximus and Sphyrna zygaena which could be very rare in Syrian marine waters, or does not existed in the region any more. Centrophorus granulosus was recorded in the Syrian marine waters by [1], but wrongly identified as Centrophorus machiquensis.

The most abundant family was the Squalidae, contributing $28.33 \%$ to the total number of recorded shark species, with the next most abundant family was the Scyliorhinidae, contributing $28.31 \%$, whereas the lowest abundant family was Alopidae $(0.26 \%)$ represented by Alopias superciliosus species. The most abundant species in the catch composition were Galeus melastomus $(26.85 \%)$, Squalus blainvillei (26.72\%) and Carcharhinus plumbeus (14.13\%) (Table 1). Other species with relatively high occurrence were Hexanchus griseus (5.80\%), Mustelus mustelus (5.20\%), Centrophorus uyato (5.88\%), and Centrophorus granulosus (4.23\%). Conversely, the most weighted family was Hexanchidae contributing $47.02 \%$ of total weight landing, the next weighted family was Carcharhinidae contributing 41.57\%. Hexanchus griseus was the most weighted species, with next Carcharhinus plumbeus contributing $46.15 \%$ and $31.14 \%$ respectively (Table 1).

Abundant index, status on regional Red List of Mediterranean, and percentage of weight and numeral of sharks were shown in Table 1. There were three abundant species (C. plumbeus, Galeus 
Species Composition, Diversity and Length Frequency of By-Catch Sharks from the Syrian Coast

melastomus and Squalus blainvillei), and five common species (H. griseus, Heptranchias perlo, Mustelus mustelus, Centrophorus moluccensis, Centrophorus granulosus) in Syrian sharks fisheries.

The means of H, D and $\mathrm{J}$ through the period of study (mean \pm S.D.) were $(1.73 \pm 0.21),(2.03 \pm 0.40)$ and $(0.67 \pm 0.09)$ respectively. Seasonally variations of the three ecological indices were shown in Figure 1. The highest mean of $\mathrm{H}$ values was in spring $(1.79 \pm 0.33)$, followed by autumn $(1.78 \pm$ $0.19)$, winter $(1.75 \pm 0.24)$, and summer $(1.60 \pm 0.09)$. Additionally, the highest mean of $\mathrm{D}$ values was in spring $(2.54 \pm 0.25)$, followed by autumn $(1.93 \pm 0.42)$, summer $(1.87 \pm 0.24)$, and winter $(1.79 \pm$ $0.21)$. While the highest mean of $\mathbf{J}$ values was in winter $(0.75 \pm 0.09)$, followed by autumn $(0.68 \pm$ $0.06)$, spring $(0.63 \pm 0.10)$, and summer $(0.62 \pm 0.03)$. This study provided first details on diversity indices and length structure of shark fishery in the Syrian marine waters and in Mediterranean Sea.

Table1. The contribution by number, biomass, index of abundance and status on regional Red List of Mediterranean at the major landing sites for each by-catch species off the Syrian waters

\begin{tabular}{|c|c|c|c|c|}
\hline Scientific name & 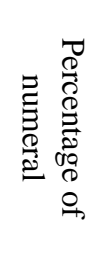 & 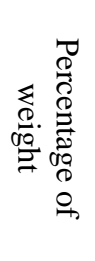 & 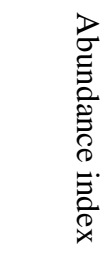 & 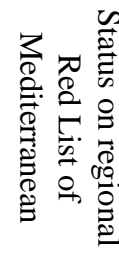 \\
\hline Hexanchidae & 9.12 & 47.02 & & \\
\hline Hexanchus griseus & 5.80 & 46.15 & $\mathrm{C}$ & VU \\
\hline Heptranchias perlo & 3.32 & 0.87 & $\mathrm{C}$ & VU \\
\hline Carcharhinidae & 15.85 & 41.57 & & \\
\hline Carcharhinus plumbeus & 14.13 & 31.14 & $\mathrm{~A}$ & EN \\
\hline Carcharhinus obscurs & 1.72 & 10.43 & $\mathrm{~F}$ & DD \\
\hline Lamnidae & 1.28 & 125 & & \\
\hline Isurus oxyrinchus & 1.28 & 1.25 & $\mathrm{~F}$ & CR \\
\hline Triakidae & 5.20 & 1.87 & & \\
\hline Mustelus mustelus & 5.20 & 1.87 & $\mathrm{C}$ & EN \\
\hline Scyliorhinidae & 28.32 & 1.14 & & \\
\hline Galeus melastomus & 26.85 & 1.11 & $\mathrm{~A}$ & $\mathrm{LC}$ \\
\hline Syliorhinus canicula & 1.47 & 0.03 & $\mathrm{~F}$ & $\mathrm{LC}$ \\
\hline Squalidae & 28.33 & 2.88 & & \\
\hline Squalus blainvillei & 26.72 & 2.68 & A & DD \\
\hline Squalus megalops & 1.61 & 0.2 & $\mathrm{~F}$ & DD \\
\hline Alopiidae & 0.26 & 0.76 & & \\
\hline Alopias superciliosus & 0.26 & 0.76 & $\mathrm{O}$ & DD \\
\hline Centrophoridae & $\mathbf{1 0 . 3 5}$ & 2.77 & & \\
\hline Centrophorus granulosus & 4.48 & 1.47 & $\mathrm{C}$ & VU \\
\hline Centrophorus uyato & 5.87 & 1.29 & $\mathrm{C}$ & $*$ \\
\hline Dalatiidea & 0.65 & 0.31 & & \\
\hline Dalatias licha & 0.65 & 0.31 & $\mathrm{O}$ & DD \\
\hline Oxynotidae & 0.17 & 0.04 & & \\
\hline Oxynotus centrina & 0.17 & 0.04 & $\mathrm{O}$ & $\mathrm{CR}$ \\
\hline Squatiniidae & 0.47 & 0.39 & & \\
\hline Squatina aculeata & 0.16 & 0.19 & $\mathrm{O}$ & $\mathrm{CR}$ \\
\hline Squatina oculata & 0.31 & 0.20 & $\mathrm{O}$ & $\mathrm{CR}$ \\
\hline
\end{tabular}

Index of abundance: A, abundant (>1000); C, common (200-1000); F, frequent (100-200); O, occasional (10100). Status: CR: Critically Endangered, VU: Vulnerable, DD: Data Deficient, EN: Endangered, C: Least Concern, *: Not Evaluated. 

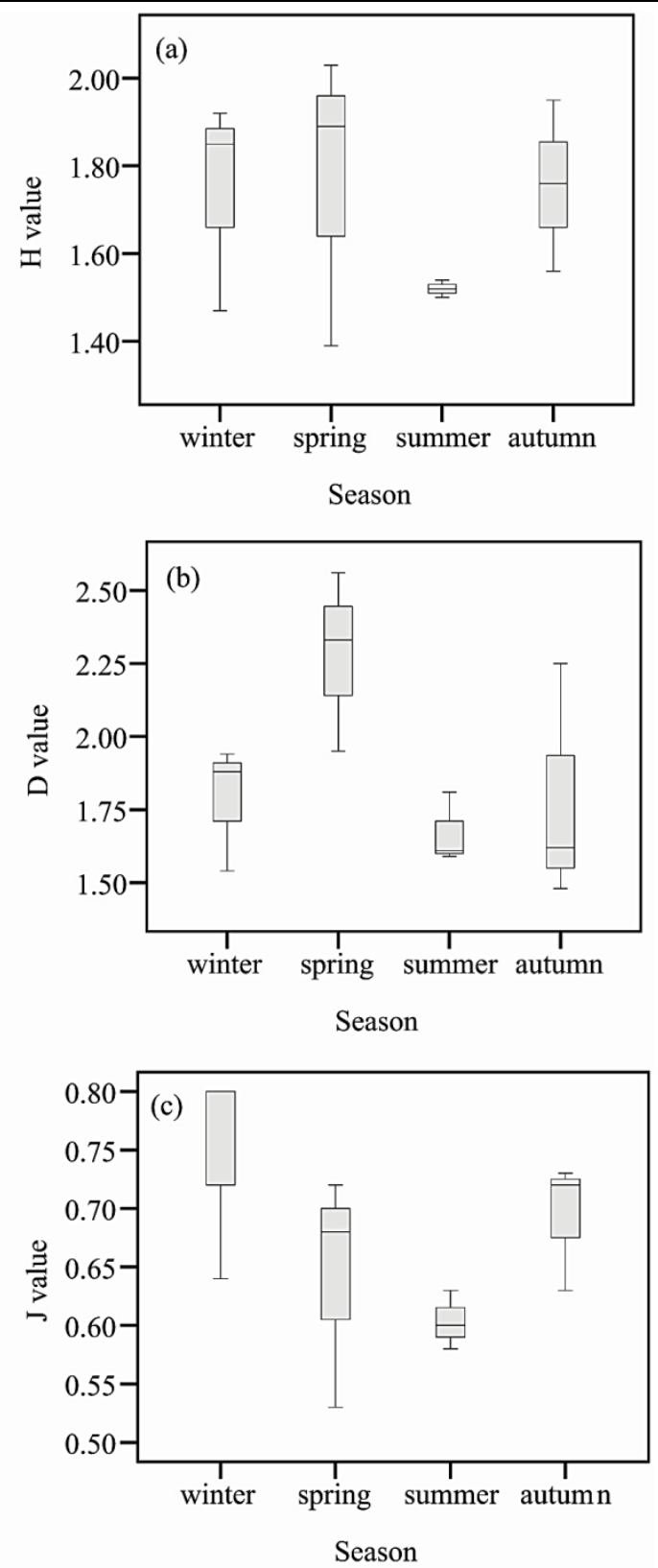

Figure1. Changes of diversity indices seasonally for by-catch sharks: (a); diversity index H, (b); qualitative richness factor $D,(c)$; evenness factor

The highest values of $\mathrm{H}$ and $\mathrm{D}$ were in spring because of caught high numbers of species $S$ and numbers of species individuals $N$ in this season, which can be caused by the movements of species individuals toward coast to bearing and searching for feeds. While the highest value of $\mathbf{J}$ was in winter due to the low numbers of species $\mathrm{S}$.

[14] reported that the mean $\mathrm{H}$ value for the sharks species caught by longlines ( 25 species, $\mathrm{N}=2601$ ) of Caribbean and Atlantic (Venezuela) during the period 1994 to 2003 were between $(1.17 \pm 0.09)$ and $(2.10 \pm 1.09)$ and between $(0.38 \pm 0.17)$ and $(1.90 \pm 0.13)$, respectively. Additionally, they stated that the shark diversity levels in both geographic areas were higher at the beginning of the time series, from approximately 1995 to 1998. [15] analyzed the diversity of oceanic predatory fishes, including sharks, in the western Atlantic and found a diminishing trend in diversity with respect to time.

Estimates of diversity levels in fishery studies can be useful as changes can be detected in the structure of commercially exploited populations. The application of diversity indices in chondrichthyans fisheries is rarely in general. [14] reported that the application of diversity indices in fisheries biology is relatively recent, and few studies using this technique have been reported.

Total length, weight, sex ratio and fishing gear types of the abundant and common sharks species landed are summarized in table 2. 
Species Composition, Diversity and Length Frequency of By-Catch Sharks from the Syrian Coast

Table 2. Length, weight and sex ratio of the abundant and common by-catch sharks landed by fishing gears at main landing site during (Syria) November 2014 - October 2016.

\begin{tabular}{|c|c|c|c|c|c|}
\hline Species & $\begin{array}{c}\text { Main type of fishing } \\
\text { gears }\end{array}$ & $\begin{array}{c}\text { Length } \\
\text { range } \\
(\mathrm{cm})\end{array}$ & $\begin{array}{c}\text { Weight } \\
\text { range }(\mathrm{kg})\end{array}$ & $\begin{array}{c}\text { Sex ratio } \\
(\mathrm{M}: \mathrm{F})\end{array}$ & $\begin{array}{c}\text { Peak of } \\
\text { season } \\
\text { landing }\end{array}$ \\
\hline Hexanchus griseus & longlines-trawls & $85-345$ & $4-335$ & $1: 1.74$ & autumn \\
\hline Hepranchias perlo & trawls- nets & $20-124$ & $0.1-6$ & $1: 1.14$ & spring \\
\hline Carcharhinus plumbeus & nets- longlines & $45-300$ & $1-161$ & $1: 2$ & autumn \\
\hline Mustelus mustelus & trawls & $50-141$ & $0.2-9$ & $1: 1.36$ & autumn \\
\hline Galeus melastomus & trawls & $27-70$ & $0.1-1$ & $1: 1.17$ & autumn \\
\hline Squalus blainvillei & trawls & $28-82$ & $0.1-4$ & $1: 1.37$ & summer \\
\hline Centrophorus granulosus & trawls- longlines & $46-105$ & $0.4-6$ & $1: 1.48$ & summer \\
\hline Centrophorus uyato & trawls-longlines & $47-100$ & $0.4-5.6$ & $1: 1.15$ & summer \\
\hline
\end{tabular}

\section{Hexanchus griseus}

TL ranged between 102 and $310 \mathrm{~cm}$ for males and between 85 and $345 \mathrm{~cm}$ for females. Common TL ranged from 155 to $230 \mathrm{~cm}$ for males and from 175 to $275 \mathrm{~cm}$ for females. This species was recorded in all months through the period of study. Females constituted $63.5 \%$ of species catches. Its caught appeared a significant difference between seasons $\left(\mathrm{X}^{2}=11.441, \mathrm{P}=0.010\right)$, peak of season landing was in autumn (Fig. 2a), a high proportion of juveniles was recorded in spring (Fig. 3a). [16] suggested that males and females of $H$. griseus maturing at 300 and $350 \mathrm{~cm}$ TL, respectively. In Mediterranean Sea. Consequently, about $97 \%$ of males and $100 \%$ of females were immature of catches (Fig. 4a).

\section{Hepranchias perlo}

TL ranged between 27 and $117 \mathrm{~cm}$ for males and between 20 and $124 \mathrm{~cm}$ for females. Common TL ranged from 60 to $100 \mathrm{~cm}$ for males and from 55 to $100 \mathrm{~cm}$ for females. $H$. perlo was presented in all months through year except February. Percentage of females catches was 53.2\%. There was a significant difference between caught seasons $\left(\mathrm{X}^{2}=16.400, \mathrm{P}=0.001\right)$, peak of season landing was in spring (Fig. 2b) with a high percentage of juveniles (Fig. 3b). [17] reported that males and females of H. perlo maturing at $81 \mathrm{~cm} \mathrm{TL}$ and $97 \mathrm{~cm}$ TL, respectively in Syrian marine waters. Therefore, about $50 \%$ of males and $74 \%$ of females were immature of catches (Fig. $4 \mathrm{~b}$ ).

\section{Carcharhinus plumbeus}

TL ranged between 46 and $250 \mathrm{~cm}$ for males and between 45 and $300 \mathrm{~cm}$ for females. Common TL ranged from 125 to $150 \mathrm{~cm}$ for males and from 135 to $160 \mathrm{~cm}$ for females. C. plumbeus was recorded in all months through year. Females contributed $66.8 \%$ of species catches. A significant difference between caught seasons was founded $\left(\mathrm{X}^{2}=11.644, \mathrm{P}=0.009\right)$, peak of season landing was in autumn (Fig. 2c), a high percentage of juveniles was recorded in winter (Fig. 3c). Males and females of $C$. plumbeus maturing at $160 \mathrm{~cm}$ and $172 \mathrm{~cm}$ TL, respectively in Mediterranean Sea (Tunisian coast) [18]. Based on this information, about $85 \%$ of males and $88 \%$ of females were immature of catches (Fig. 4c).

\section{Mustelus mustelus}

TL ranged between 55 and $133 \mathrm{~cm}$ for males and between 50 and $141 \mathrm{~cm}$ for females. Common TL ranged from 73 to $88 \mathrm{~cm}$ for males and from 77 to $100 \mathrm{~cm}$ for females. This species was founded in all months of year. Females constituted $57.7 \%$ of species catches. Its caught appeared a significant difference between seasons $\left(\mathrm{X}^{2}=11.600, \mathrm{P}=0.009\right)$, peak of season landing was in winter (Fig. $2 \mathrm{~d}$ ), while a high percentage of juveniles was recorded in spring (Fig. 3d). According to [7] males and females of M. mustelus (Syrian coast) species matured at $101 \mathrm{~cm}$ and $105 \mathrm{~cm}$ TL, respectively. Thus, immature males and females contributed $90 \%$ and $83 \%$ of species catches (Fig. 4d).

\section{Galeus melastomus}

TL ranged between 27 and $63 \mathrm{~cm}$ for males and between 32 and $70 \mathrm{~cm}$ for females. Common TL ranged from 41 to $50 \mathrm{~cm}$ for males and from 44 to $55 \mathrm{~cm}$ for females. G. meastomus was recorded in all months of year. Percentage of females catches was 53.9\%. Its caught appeared no significant difference between seasons $\left(\mathrm{X}^{2}=10.800, \mathrm{P}=0.013\right)$, peak season of landing was in autumn (Fig. 2e), 
while a peak season of juveniles landing was in winter (Fig. 3e). [19] noted that males and females of G. melastomus matured at 38 and $43 \mathrm{~cm}$ TL, respectively. Based on this information, immature males and females constituted about $10 \%$ and $21 \%$, respectively. (Fig. 4 e).
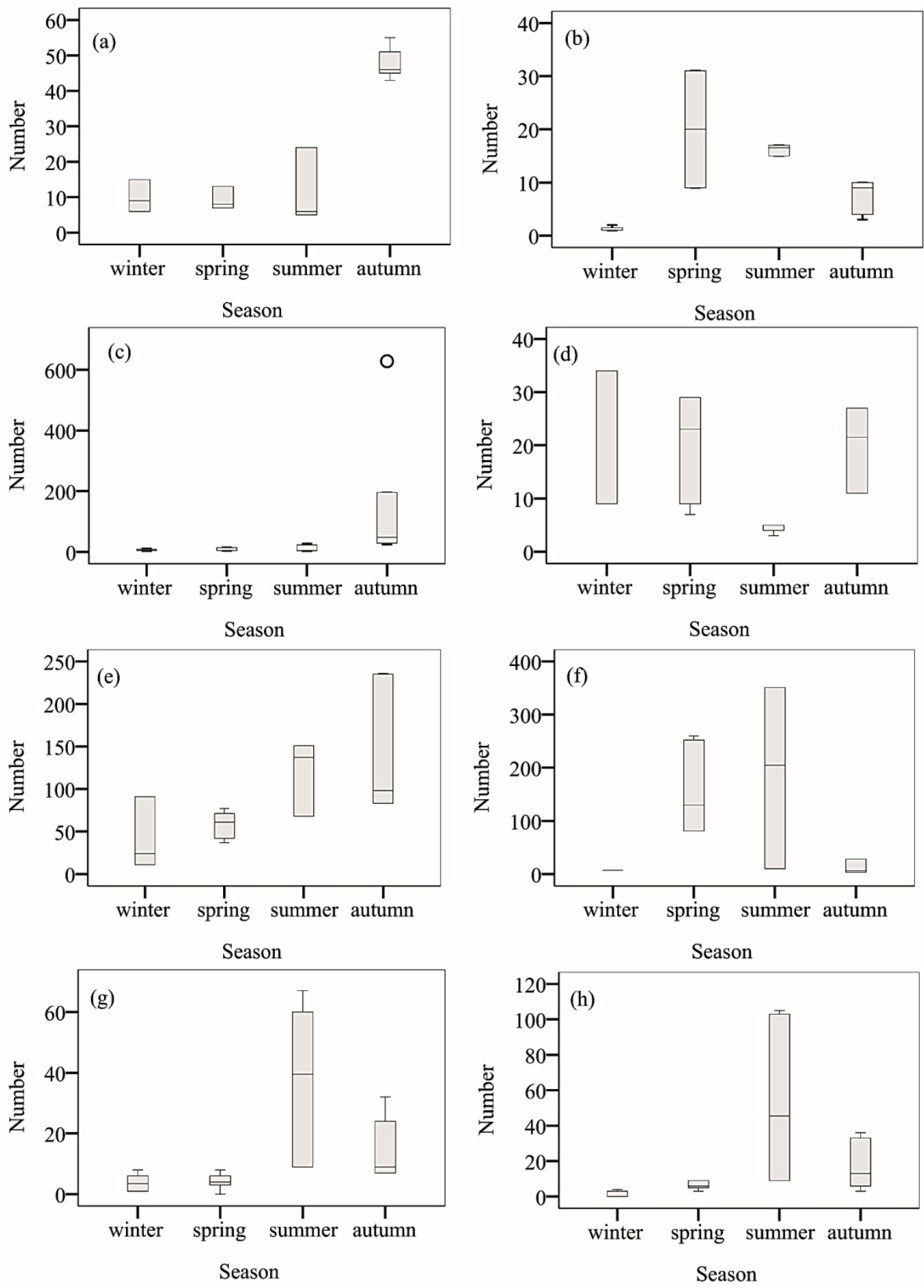

Figure 2. Changes of caught specimens number per season; (a) H. griseus, (b); H. perlo, (c); C. plumbeus, (d); M. mustelus (e); G. melastomus , (f); S. blainvillei, (g); C. moluccensis , (h); C. granulosus

\section{Squalus blainvillei}

TL ranged between 28 and $78 \mathrm{~cm}$ for males and between 29 and $82 \mathrm{~cm}$ for females. Common TL ranged from 44 to $53 \mathrm{~cm}$ for males and from 46 to $58 \mathrm{~cm}$ for females. This species was presented in all months of year except December and January. Females contributed $57.3 \%$ of species catches. Its caught appeared a significant difference between seasons $\left(\mathrm{X}^{2}=10.800, \mathrm{P}=0.013\right)$, peak of season landing was in summer (Fig. 2f), while a peak of juveniles landing was in spring (Fig. 3f). Males and females of S. blainvillei matured at 46 and $56 \mathrm{~cm}$ TL [20], respectively. Therefore, about $33 \%$ of males and $71 \%$ of females were immature in species catches (Fig. 4f). 

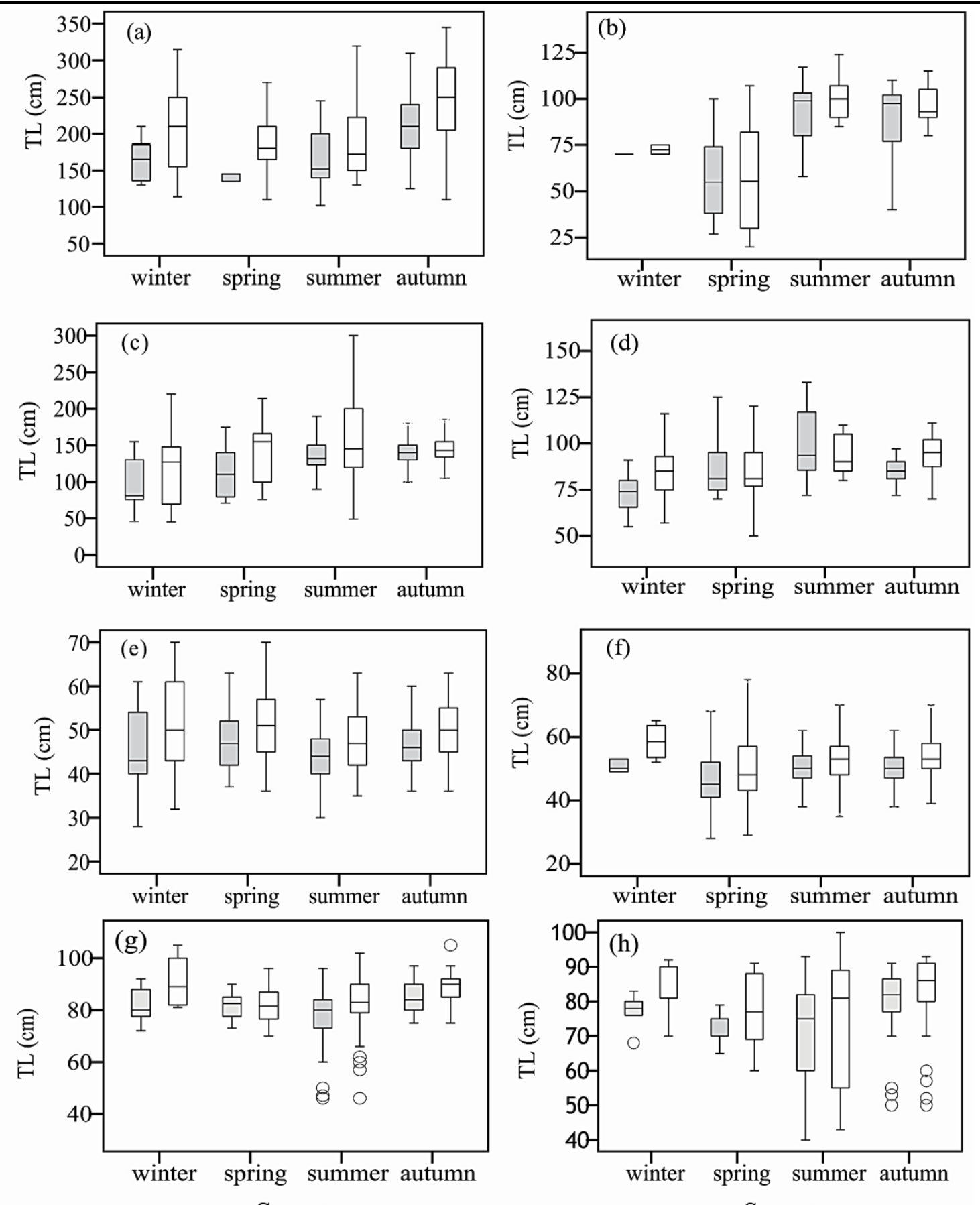

Season

Season

Figure 3. Size (TL) variations of abundant and common of by-catch sharks per season off Syria coast. Males (gray), females (white): (a); H. griseus ,(b); H. perlo ,(c); C. plumbeus, (d); M. mustelus (e); G. melastomus , (f); S. blainvillei, (g); C. granulosus, (h); C. uyato

\section{Cenrophorus uyato.}

TL ranged between 47 and $90 \mathrm{~cm}$ for males and between 50 and $100 \mathrm{~cm}$ for females. Common TL ranged from 70 to $80 \mathrm{~cm}$ for males and from 75 to $80 \mathrm{~cm}$ for females. This species was recorded in all months of year except January. Females constituted 53.4\% of species catches. Its caught appeared no significant difference between seasons $\left(X^{2}=13.448, P=0.004\right)$, peak of season landing was in summer (Fig. 2g), while a peak of juveniles landing was in spring (Fig. 3g). Males and females of $C$. uyato off Syrian marine warts matured at $79.2 \mathrm{~cm}$ and $86.7 \mathrm{~cm}$ TL [17], respectively. Therefore, about $62 \%$ of males and $66 \%$ of females were immature (Fig. $4 \mathrm{~g}$ ).

\section{Centrophorus granulosus}

TL ranged between 46 and $97 \mathrm{~cm}$ for males and between 46 and $105 \mathrm{~cm}$ for females. Common TL ranged from 77 to $85 \mathrm{~cm}$ for males and from 80 to $90 \mathrm{~cm}$ for females. C. granulosus was recorded in 
all months of years. Females constituted $59.6 \%$ of species catches. A significant difference between caught seasons was founded $\left(\mathrm{X}^{2}=15.915, \mathrm{P}=0.001\right)$, peak of season and juveniles landing were in summer (Fig. 2h and Fig. 3h). [21] reported that males and females of C. granulosus matured at 80 and $90 \mathrm{~cm} \mathrm{TL}$, respectively. Consequently, about $37 \%$ of males and $68 \%$ of females were immature in species catches (Fig. 4h).
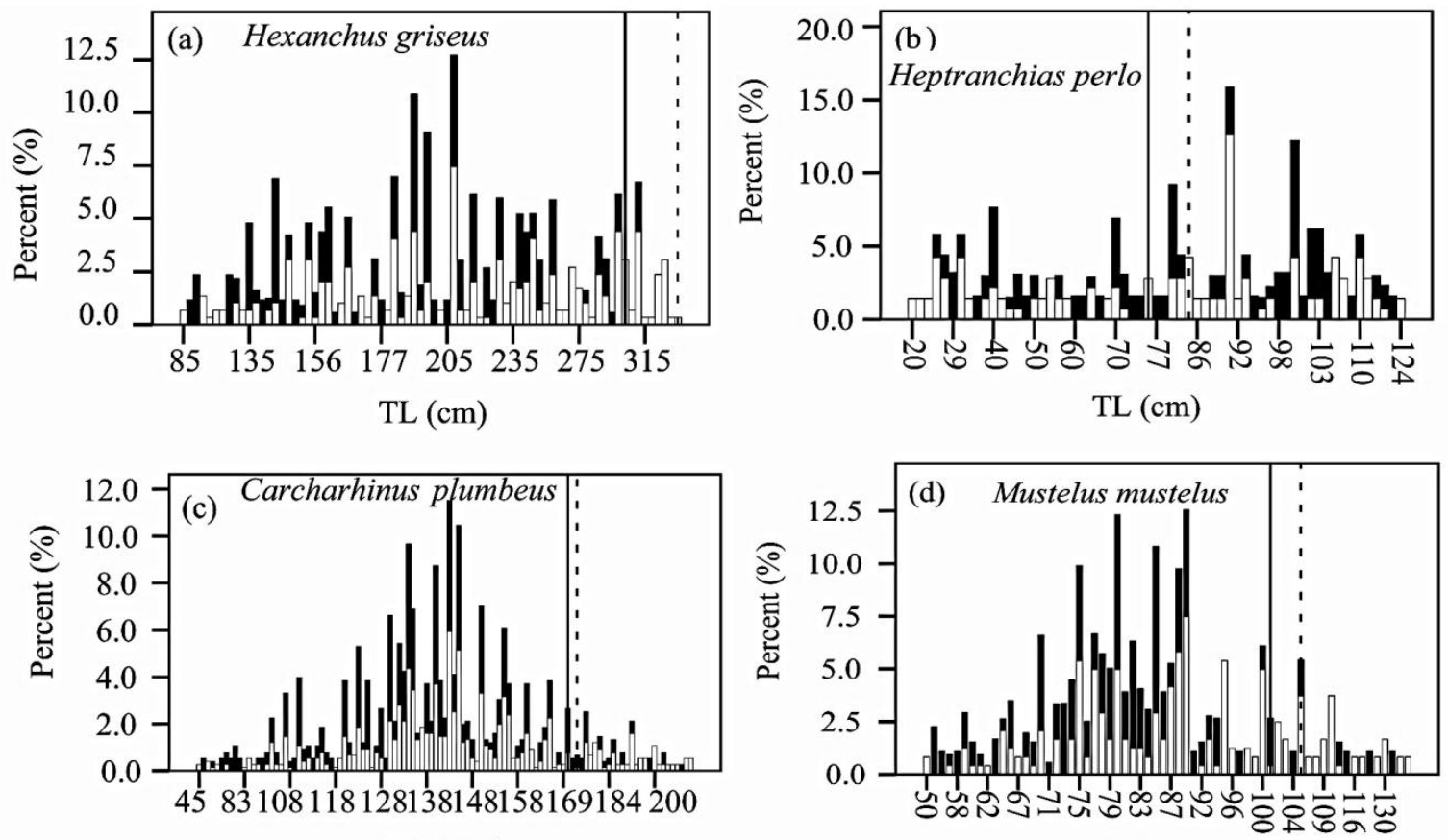

TL $(\mathrm{cm})$
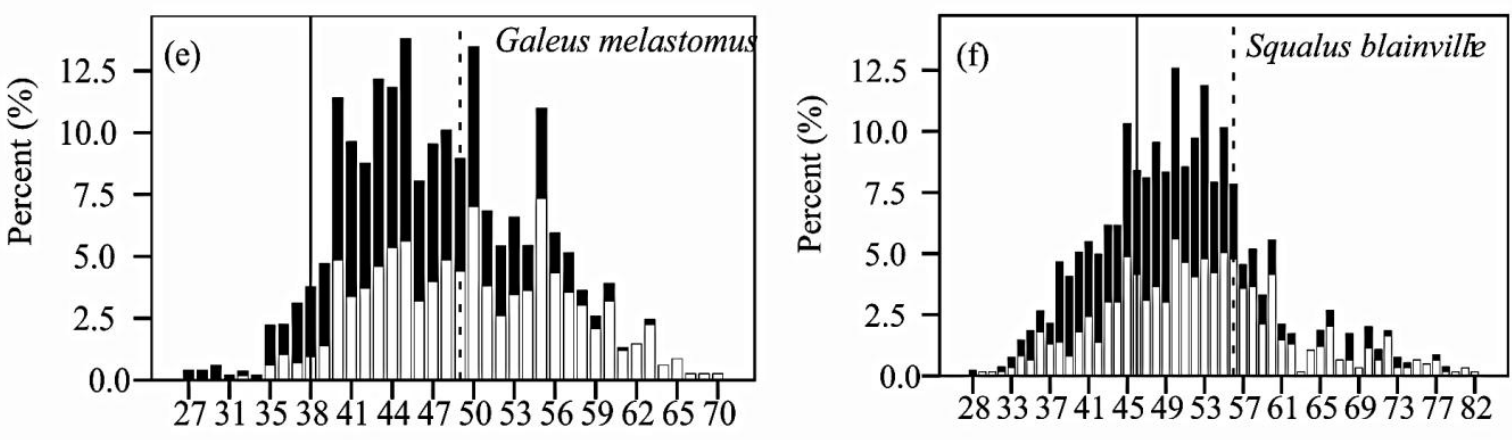

TL $(\mathrm{cm})$

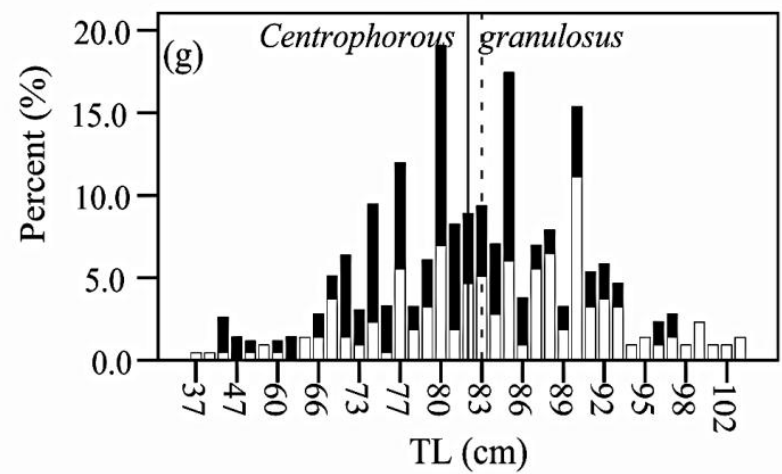

$\mathrm{TL}(\mathrm{cm})$

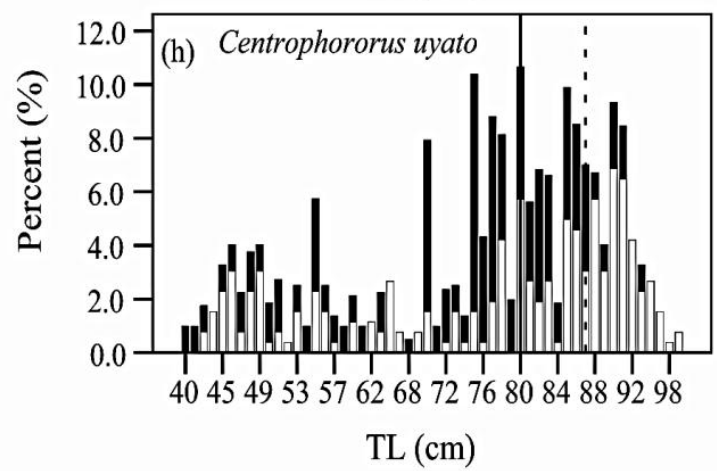

Figure 4. Total length (TL) frequency distributions (percent of species catch) of the abundant and common bycatch sharks off Syrian coast. Males (black), females (white). Vertical lines indicate maturity size of males (sporadic) and females (continuous) following literature: (a); H. griseus ,(b); H. perlo , (c); C. plumbeus, (d); M. mustelus (e); G. melastomus, (f); S. blainvillei, (g); C. granulosus, (h); C. uyato

There were three possible nursery areas for H. griseus (northern Ras Albassit, northern Lattakia and northern Tartous) in Syrian marine waters. Moreover, three possible nursery areas were in the region for C. plumbeus (one area southern Lattakia and two areas southern Tartous). While there were two 
possible nursery areas for $M$. mustelus (against Lattakia and middle distance between Jablah and Banias) (Fig. 5).

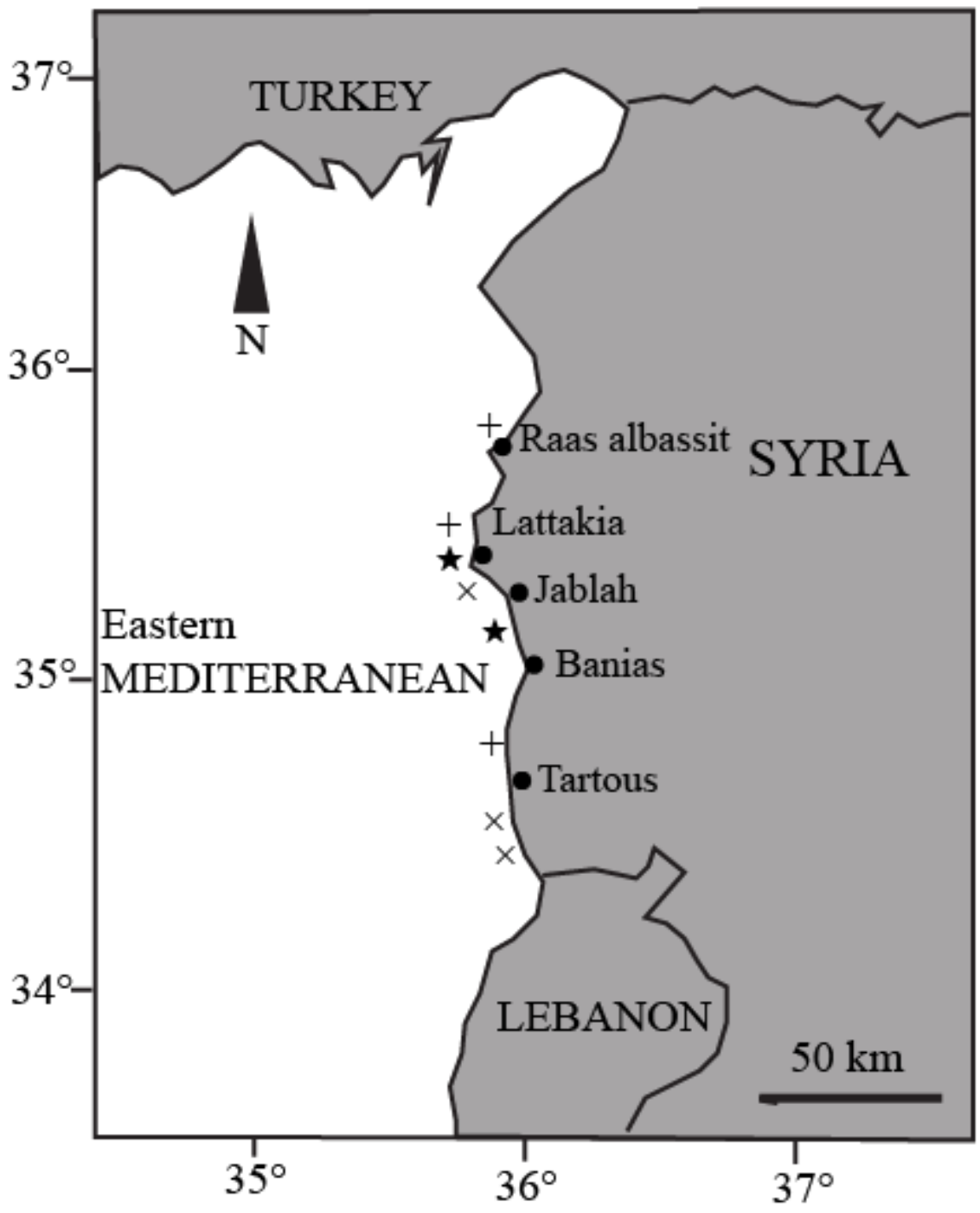

Figure 5. Geographic distribution of possible nursery areas for three species (H. griseus; +, C. plumbeus; $\times$, M. mustelus; *, black circles; main cities) in Syrian marine waters.

The very economically important species being caught in plentiful quantities and highly consumable: C. plumbeus, M. mustelus C. uyato, H. griseus, and S. blanvllei. Moderate economically important species either for being caught in little quantities with high efforts in fishing, or for their little demand for human consumption, or may be both reasons: $H$. perlo, I. oxyrinchus, A. superciliosus, $C$. obscurus, D. licha, S. squatina, S. oculata, S. aculata, in Syrian marine waters [2].

The seasonal variation findings are in agreement with [22] Buencuerpo et al. (1998) and [23] Megalofonou (2005), who reported maximum catch rates in April (spring) and September (autumn). Certain water temperature preferences of sharks force them to shift to deeper, cooler water masses, especially in tropical and subtropical areas. In these depths they are less vulnerable to surface longlining and that reflects in lower catch rates [24, 25, 26, 27].

The two pelagic species H. griseus (common), C. plumbeus (abundant) and the deep-water species $M$. mustelus (common) fishery were dominance by juveniles, which considered as vulnerable, endangered and endangered, respectively, on regional Red List of Mediterranean Sea. These species were occurrence every month round year that totally composed about $25 \%$ of Syrian sharks landing. The females catches of the pelagic species $H$. perlo (common), also the three deep-water species $S$. blainvillei (abundant), C. uyato (common) and C. granulosus (common) were mostly comprised by juveniles. Which considered as vulnerable, data deficient, unknown and vulnerable, respectively, on regional Red List of Mediterranean Sea. Conversely, catches of the deep-water species G. melastomus 
was comprised by a little numbers of juveniles in both sexes. The presence of recruits both between 200 and $650 \mathrm{~m}$, a greater percentage of mature individuals in the mesobathyal than in epibathyal and homoeothermic condition in the bathyal environment of Mediterranean, this may cause by that the reproduction occurs at the lowest depths at which the species is found. More ever, the use of longlining scatter baits made them more accessible to smaller species [2]. The low percentage of $G$. melastomus recruits caused by discarding of small individuals after catch immediately because of it has no economical important.

In addition, the investigations with fishermen showed a major decline in the quantity (number and size of individuals) of shark fishery throughout last ten years, this situation caused by overfishing with the historical life characterizes of shark, represented by; large size at maturity, slow growth rate and low fecundity. These reasons make this fish group suffering from disability to complete its life cycle, as result a high proportion of juveniles were found in its catches, reached to $83 \%-100 \%$ for three species. [28] reported that there is increasing evidence that indirect effects of fishing are affecting the composition and diversity of chondrichthyan and total fish assemblages through trophic interactions, so we have to set up a monitoring program for chondrichthyan fishery and its landing.

\section{CONCLUSiONS}

The five shark species: H. griseus, H. perlo, C. plumbeus, M. mustelus and C. uyato, are facing over fishing, which probably established sustainable populations in the Syrian coast, this region could be an important resource for these species. Additionally, there is decline of species number and the quantity in the region by the time. These are serious signs threaten shark species sustainability. Consequently, major efforts, accurate marine surveys and more biological studies would be needed to management and conservation these species.

\section{REFERENCES}

[1] Ali M. and Saad A., Sharks and rays of the Syrian marine waters, Bassel Al-Assad Journal for engineering sciences 17: 45-76 (2003) (in Arabic with abstract in English)

[2] Saad A., Ali M. and Seret B., Shark exploitation and conservation in Syria, The proceedings of the international workshop on Mediterranean cartilaginous fish with emphasis on southern and eastern Mediterranean, Atakoy Marina, Istanbul, Turkey, Pp. 202-208 (2006)

[3] Ali M., Saad A., Ben Amor M. and Capape C., First records of the Honeycomb Stingray, Himantura uarnak (Forskal, 1775), off the Syrian coast (Eastern Mediterranean), (Chondrichthyes: Dasyatidae), Journal of Zoology in the Middle East 49: 104-106 (2010) doi: 10.1080/09397140.2010.10638397

[4] Ali M., Saad A., Reynaud C. and Capape C., Occurrence of basking shark, Cetorhinus maximus (Elasmobranchii: Lamniformes: Cetorhinidae), off the Syrian coast (eastern Mediterranean) with first description of egg case, Acta Ichthyologica Et Piscatoria 42: 335-339 (2012) doi: 10.3750/ AIP2012.42.4.07

[5] Hassan M., Occurrence of large-eyed rabbitfish Hydrolagus mirabilis, Chimaeridae, in Syrian waters (eastern Mediterranean), Marine Biodiversity Records 6: e7 (2013)doi: 10.1017/S175526721200111X

[6] Ali, M., Saad, A., Christian, R. and Capape, C., First records of round fantail stingray Taeniura grabata (Chondrichthyes: Dasyatidae) off the Syrian coast (eastern Mediterranean). Jour, Zoology in the Middle East 59 (4): 176-178 (2013)

[7] Ali F. M., Reproductive biology and feeding of two cartilaginous fish Mustelus mustelus and Rhiobatos cemiculus in Syrian marine waters, PH.D. Thesis Tishreen University. Syria. Pp. 182 (2009) (In Arabic with abstract in English).

[8] Alkusairy, H., Ali M., Saad, A., Reynaud, C. and Capapé C., Maturity, reproductive cycle and fecundity of spiny butterfly ray, Gymnura altavela (Elasmobranchii: Lamniformes: Gymnuridae) from the coast of Syria (eastern Mediterranean), Acta Ichthyologica Et Piscatoria 44 (3): 229-240 (2014) doi: 10.3750/AIP2014.44.3.07

[9] Alkusairy, H. and Saad, A., Some morphological and biological aspects of longnosed skate, Dipturus oxyrinchus (Elasmobranchii: Rajiformes: Rajidae) in Syrian marine waters (eastern Mediterranean). Acta Ichthyologica Et Piscatoria 47 (4): 371-383 (2017) DOI: 10.3750/AIEP/02283

[10] Compagno L. J. V., FAO species catalogue vol. 4, part 1: shark of the world: an annotated and illustrated catalogue of shark species known to date. FAO fisheries Synop, Rome: FAO, 125: 1-249 (1984)

[11] Compagno L. J. V., FAO species catalogue vol. 4, part 1: shark of the world: an annotated and illustrated catalogue of shark species known to date. FAO fisheries Synop, Rome: FAO, 125: 251-655 (1984) 
[12] Serena F., Field identification guide to the sharks and rays of the Mediterranean and Black Sea, FAO Species Identification Guide for Fishery Purposes, Rome: FAO, (2005)

[13] Shannon C.E. and Weaver W.,The mathematical theory of communication ,University of Urbana: Illinois press, (1949)

[14] Margalef R., Perspectives in ecology, Chicago: University of Chicago press, (1968)

[15] Pielou E.C., Mathematical ecology, New York: John Wiley, 1977.

[16] Tavares R. and Freddy A., Species diversity, relative abundance and length structure of oceanic sharks caught by the Venezuelan longline fishery in the Caribbean Sea and western-central Atlantic, Zootecnia Trop 26(4): 489-503 (2008)

[17] Worm B., Lotze H.K. and Myers R.M., Predator diversity hotspots in the blue ocean. Proc. Nat. Acad. Sci. 100: 9884-9888. (2003)

[18] Capapé C., Hemida F., Guelorget O., Barrull J., Mate I., Ben Souissi J.and Bradai M.N., Reproductive biology of the Bluntnose sixgill shark Hexanchus griseus (Bonnaterre, 1788) (Chondrichthyes: Hexanchidae) from the Mediterranean Sea: a review, Acta Adriat 45: 95-106 (2004)

[19] Ali M., Saad A., Kurbaj H., and Jnaidi S., Biology of reproductive and feeding of three commercial shark species in Syrian marine water, The Higher Commission for Scientific Research, final report, Syria, Pp 57 (2013) (in Arabic)

[20] Saidi B., Bradai M.N., Bouain A., Guélorget O. and Capapé, C., The reproductive biology of the sandbar shark, Carcharhinus plumbeus (Chondrichthyes: Carcharhinidae), from the Gulf of Gabes (southern Tunisia, central Mediterranean), Acta Adriat 46: 47-62 (2005)

[21] Ragonese, S., Nardone, G., Ottonello, D., Gancitano, S., Giusto, G.B. and Sinacori, G., Distribution and biology of the Blackmouth catshark Galeus melastomus in the Strait of Sicily (Central Mediterranean Sea), Mediterranean Marine Science 10: 55-72 (2009) doi: 10.12681/mms.122

[22] Kousteni V. and Megalofonou P., Reproductive biology and embryonic development of Squalus blainvillei in the eastern Mediterranean Sea, Scientia Marina 75: 237-249 (2011) doi: 10.3989/scimar.2011.75n2237

[23] Capapé, C., Nouvelle description d22e Centrophorus granulosus (Schneider, 1801) (Pisces, Squalidae). Donnees sur la biologie de la reproduction et le regime alimentaire des specimes des cotes tunisiennes, Bull Inst Natn Scient Tech Oceanogr Peche Salammbo 12: 97-141 (1985)

[24] Buencuerpo V., Rios S. and Moron J., Pelagic sharks associated with the swordfish, Xiphias gladius, fishery in the eastern North Atlantic Ocean and the Strait of Gibraltar. Fish . Bull. 96: 667-685 (1998)

[25] Megalofonou P., Damalas D. and Yannopoulos C., Composition and abundance of pelagic shark by-catch in the eastern Mediterranean Sea, Cybium 29(2): 135-140 (2005)

[26] Strasburg D.W., Distribution, abundance, and habits of pelagic sharks in the central Pacific Ocean, Fish. Bull. 58: 335-361 (1958)

[27] Carey F.G. and Scharold J., Movements of blue sharks (Prionace glauca) in depth and course, Mar. Biol. 106: 329-342 (1990)

[28] Nakano H., Age, reproduction and migration of blue shark in the North Pacific Ocean, Bull. Natl. Res. Inst. Far Seas Fish. 31: 141-219 (1994)

[29] Bigelow K .A., Boggs C.H. and He X., Environmental effects on swordfish and blue shark catch rates in the US North Pacific longline fishery. Fish. Oceanogr. 8(3): 178-198 (1999)

[30] Stevens J. D., Bonfil R., Dulvy N. K. and Walker P. A., The effects of fishing on sharks, rays, and chimaeras (chondrichthyans), and the implications for marine ecosystems, ICES Journal of Marine Science 57: 476-494 (2000)

Citation: H. ALKUSAIRY, A. SAAD, "Species Composition, Diversity and Length Frequency of By-Catch Sharks from the Syrian Coast ", International Journal of Research Studies in Zoology, vol. 4, no. 1, p. 11-21, 2018. http://dx.doi.org/10.20431/2454-941X.0401003

Copyright: (C) 2018 Authors. This is an open-access article distributed under the terms of the Creative Commons Attribution License, which permits unrestricted use, distribution, and reproduction in any medium, provided the original author and source are credited. 